\title{
BRI E-Banking Services Quality Analysis in BRI Panakkukang Branch During Covid-19 Pandemic
}

\author{
Eljihad Akbari Syukriah Mathory ${ }^{1}$, Husnul Fauziah AR $^{2}$ \\ Polytechnic of STIA LAN Makassar \\ \{eljihad.asm@stialanmakassar.ac.id\}
}

\begin{abstract}
Covid-19 pandemic caused customers of PT. Bank Rakyat Indonesia (Persero) Tbk, Panakkukang branch got closer to e-banking services; however, there were still a lot of complaints from the customers. The objective of the study was to understand how the quality of BRI e-banking services affected customer satisfaction and to determine differences in the quality of BRI e-banking services at the Panakkukang Branch during the Covid-19 pandemic. This study applied quantitative method with 100 respondents. The data collection technique was carried out using a questionnaire which was processed using SPSS ver. 25 and reviewing the documents. The results of the study showed that $\mathrm{H}_{\mathrm{o}}$ is rejected, and $\mathrm{H}_{\mathrm{a}}$ is accepted, which means that the quality of e-banking services consisting of speed, security, accuracy and trust has positive and significant effect on customer satisfaction during the Covid-19 pandemic. The quality of BRI e-banking services at the Panakkukang Branch is in very good category with the percentage of the speed indicator $80.75 \%$, security $78.67 \%$, accuracy $79.8 \%$ and trust $81.05 \%$ from the expected $100 \%$. The difference in the quality of e-banking services during the Covid-19 pandemic can be seen from the various additional features in several BRI e-banking services at Panakkukang Branch.
\end{abstract}

Keywords: Quality of E-Banking Service, Speed, Security, Accuracy, Trust

\section{Introduction}

Technology is currently developing very rapidly. Companies must be able to adapt to existing technological developments in order to survive. One of the most influential is the service quality of the company. Service quality can be a differentiator and determinant of a company's success compared to competitors. Companies can differentiate themselves from competitors by implementing high service quality (Anggraeni and Yasa, 2012). Various information technology-based services and facilities have had a significant impact on the banking industry today. PT Bank Rakyat Indonesia (Persero) Tbk is one of Indonesia's banks. It is the country's oldest bank and has the largest work unit in the country. PT Bank Rakyat Indonesia (Persero) Tbk must be able balance the current state of technology with the quality of service given to customers.

A virus known as covid-19 is currently causing an outbreak in Indonesia. As one of the companies affected by Covid-19, PT Bank Rakyat Indonesia (Persero) needs to be able to adjust in the face of a pandemic. In the current situation of the Covid-19 pandemic, it raises new challenges for banking and makes the use of technology closer. Customers will be accustomed to using services online platform to carry out various banking transactions electronically so that 
it will reduce customer visits at bank offices. Electronic banking services are commonly called e-banking services. E-banking challenges banks how to market e-banking and how to make changes to customers in transactions from using conventional channels (branch delivery) to using e-banking (Krishna, 2012).

There are numerous advantages in the use of e-banking services available. Because ebanking services may be accessed anytime and anywhere via the internet, cellphones, and other electronic media, customers can make transactions easier without having to queue and save time. Today, e-banking has evolved into a platform for a strategic new banking industry aimed at attracting customers and increasing customer satisfaction (Sharma, 2011). The following are the services e-banking BRI owned before and after the covid-19 pandemic.

Table 1. BRI E-Banking Service

\begin{tabular}{|llll|}
\hline No & Before the Covid-19 Pandemic & No & After the Covid-19 Pandemic \\
\hline 1 & ATM BRI & 1 & ATM BRI \\
\hline 2 & SMS Banking & 2 & SMS Banking \\
\hline 3 & Internet Banking & 3 & Internet Banking \\
\hline 4 & Mobile Banking & 4 & Mobile Banking \\
\hline 5 & BRIMO & 5 & BRIMO \\
\hline 6 & E-Buzz & 6 & E-Buzz \\
\hline 7 & BRISpot & 7 & BRISpot \\
\hline 8 & BRIZZI & 8 & BRIZZI \\
\hline 9 & Mo-Cash & 9 & Mo-Cash \\
\hline 10 & SABRINA & 10 & SABRINA \\
\hline & & & \\
& Digital Ecosystem (Junio & Smart, & \\
11 & 11 & Digital Ecosystem \\
& BRIMola, BRIBill \& BRIStore) & & BRIMola, BRIBill \& BRIStore) \\
& & & \\
\hline 12 & PINANG Smart, \\
\hline 13 & CERIA & 12 & PINANG \\
\hline 14 & BRILINK & 13 & CERIA \\
\hline & & 14 & BRILINK \\
\hline & & 15 & Digital Saving \\
\hline
\end{tabular}

After the covid-19 pandemic, PT Bank Rakyat Indonesia (Persero) Tbk now offers the most up-to-date e-banking service, namely Digital Saving and Market Web. E-banking BRI have also been widely awarded during 2019 followed by an increase in the number of users ebanking BRI. 


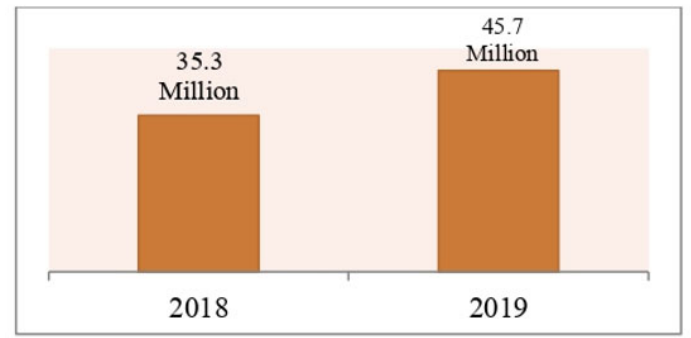

Fig 1. User of BRI E-Banking

During the covid-19 period, e-banking service BRI received extraordinary response. Immandiar (2020) recorded as many as 2.73 billion transactions in e-banking BRIas of April 2020, with a nominal transaction of Rp. 1.928 trillion. Comparison from year to year, the number of transactions in April 2020 increased by $18.71 \%$ and transaction volume increased by 7.94\% from last year (Imandiar, 2020).

PT Bank Rakyat Indonesia (Persero) Tbk, Panakkukang Branch is one of the BRI Bank branches in Makassar City. As of December 2020, there were 53.710 customers at PT Bank Rakyat Indonesia (Persero) Tbk Panakkukang Branch. The number of customers was followed by complaints from customers of PT Bank Rakyat Indonesia (Persero) Tbk, Panakkukang Branch, which continued to grow during the Covid-19 pandemic regarding the quality of services e-banking at BRI the Panakkukang Branch.

Based on initial observations made to customers of PT Bank Rakyat Indonesia (Persero) Tbk Panakkukang Branch, some of the most common complaints felt by users e-banking BRI at Panakkukang Branch during the Covid-19 pandemic, such as the process of opening an account online never finished, top up funds via mobile banking BRI did not come in, lost balances in customer accounts, failed transactions but reduced account balances, applications ebanking BRI could not be accessed until cash deposit transactions had problems.

This could indicate that during the Covid-19 pandemic, the quality of e-banking services at BRI Panakkukang Branch was not fully maximized in satisfying customers. As a result, we need a measurement that can be examined to see if there are any flaws so that it may be improved in the future. In this case, according to Lovelock and Gummesson (2004) there are four dimensions of service quality in e-banking, such as speed, security, accuracy and trust. The quality of e-banking services at BRI Panakkukang Branch during the Covid-19 pandemic can be seen from the four services. Based on the background that has been stated, the authors are interested in conducting research with the title "BRI E-Banking Services Quality Analysis in BRI Panakkukang Branch during Covid-19 Pandemic".

\section{Research Method}

The research method used in this research is to use quantitative methods. The data obtained from the questionnaire results are in the form of measuring the service quality of users e-banking BRI at the Panakkukang Branch during the Covid-19 pandemic, which is guided by the answers of research respondents filled out by customers of PT Bank Rakyat Indonesia (Persero) Tbk, Panakkukang Branch.

In this research, primary and secondary data were employed as data sources. The primary data used in this study were obtained directly from customers at PT Bank Rakyat Indonesia 
(Persero) Tbk, Panakkukang Branch, through the distrubution of questionnaires. Secondary data in question is in the form of notes, documents, BRI annual reports, internet articles, news, and other references about the quality of e-banking services at BRI Panakkukang Branch. Population is a general field consisting of objects/subjects that have certain quantities and characteristics determined by researchers to be studied so that conclusions can be drawn (Sugiyono, 2017:61). The population used in this study were customers of PT Bank Rakyat Indonesia (Persero) Tbk, Panakkukang Branch, which amounted to 53.710 customers.

In this study, the sampling technique is non-probability sampling with a purposive sampling technique that does not allow individuals of the population to have the same chance of being picked as samples or is not known to have the same opportunities (Indrawati, 2015). The sample size was calculated using the Slovin formula, resulting in a total of 100 respondents in this study, all of whom were customers of PT Bank Rakyat Indonesia (Persero) Tbk, Panakkukang Branch. Data collection techniques in this study were through questionnaires and document review. Questionnaires will be distributed to respondents by giving a set of statements to respondents by giving a score with a certain scale and then processed according to the respondent's answers. Meanwhile, the document review aims to analyze differences in the quality of BRI e-banking services during the Covid-19 pandemic. The documents to be analyzed are documents regarding the quality of e-banking services at BRI Panakkukang Branch.

In this study, researchers process data by collecting questionnaire results. The collected questionnaires will be processed using a numeric processor or MS. Excel and statistical data processing application (SPSS) to see the results of the quality of e-banking services at BRI Panakkukang Branch during the covid-19 pandemic. The data processing technique used in this study is ascale approach Likert, which displays the findings of the questionnaire data from the whole in the form of a percentage to provide a thorough picture of the state of each indicator. While the data analysis used is descriptive statistical analysis and simple linear regression analysis.

Descriptive analysis is used to analyze the data one by one based on the respondent's answers that have been filled in during the research. After the data is collected, it will be examined using a frequency table for each indicator, so that an overview of respondent's responses for each indicator can be known and an overview of the quality of services can be obtained e-banking at BRI Panakkukang Branch during the covid-19 pandemic.

The goal of simple linear regression analysis aims to determine the effect of the independent variable on the dependent variable. And will test the hypothesis in this study, namely the influence between the quality of e-banking BRI services consisting of speed, security, accuracy, and trust on customer satisfaction during the Covid-19 pandemic.

\section{Research Results}

Based on 100 answers from customer respondents of PT. Bank Rakyat Indonesia (Persero) Tbk Panakkukang Branch, can be compiled based on the characteristics of the respondents which include, gender, age, last education, purpose of using e-banking BRI, length of time being a user e-banking BRI, intensity of transactions e-banking BRI In a month, can be seen in Figure 2 , for the characteristics of respondents including occupation, last transaction time, knowledge of BRI Bank services, can be seen in Figure 3, and respondent characteristics include services e-banking BRI that have been and are currently being used and the reasons for using e-banking BRI can be seen in Figures 4 and 5. 


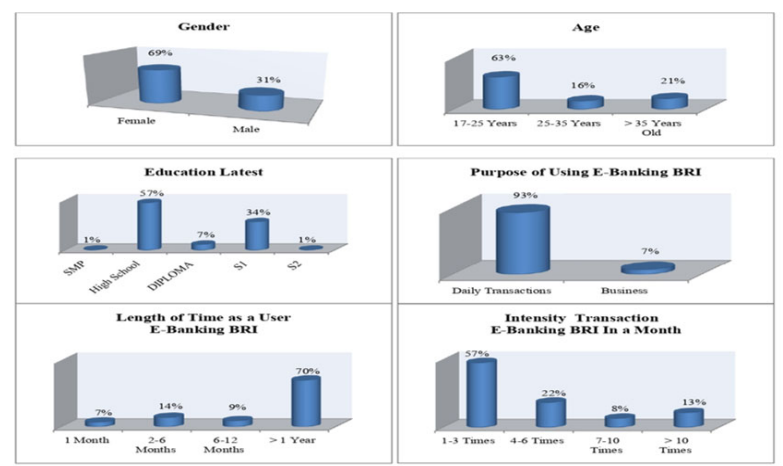

Fig 2. Analysis of Respondents Characteristic
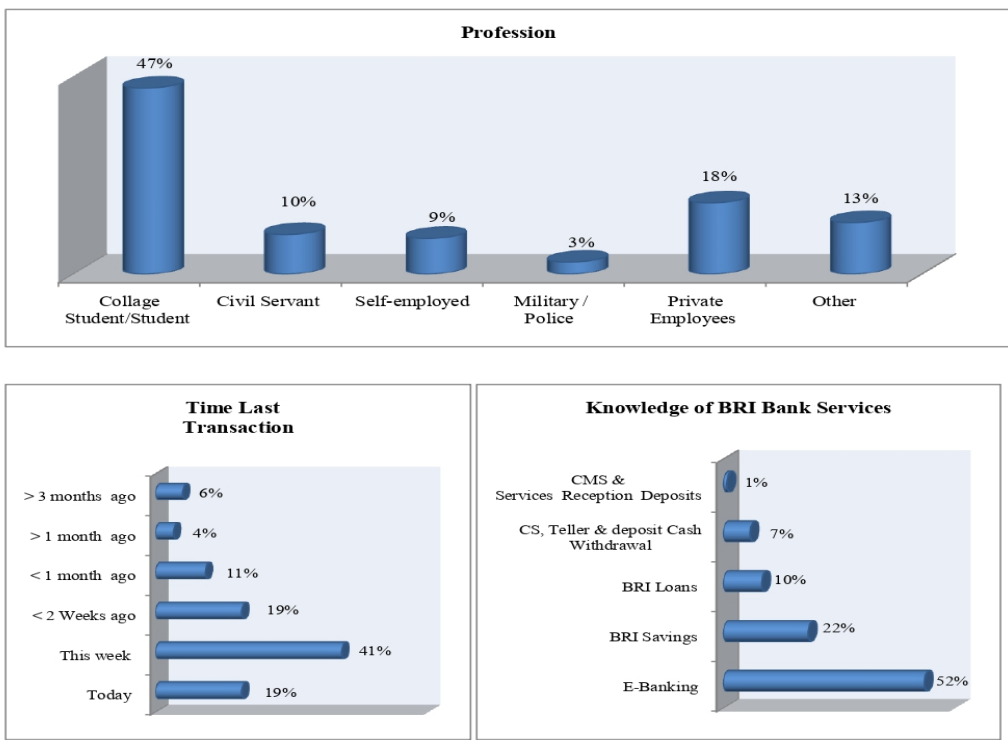

Fig 3. Analysis of Respondents Characteristic

From the results of research on 100 respondents regarding the characteristics of respondents in Figure 2, it can be seen that the characteristics of respondents based on gender can be concluded that from the characteristics of respondents based on gender the most in this study are female with a percentage of $69 \%$. Characteristics of respondents based on age most are those aged $17-25$ years with a percentage of $63 \%$. Characteristics of respondents based on the most recent education with a high school education level with a percentage of $57 \%$.

The characteristics of respondents based on the purpose of using e-banking the most are daily transactions with a percentage of $93 \%$. The characteristics of the respondents based on the length of time being the users e-banking most BRI were $>1$ year with a percentage of $70 \%$. 


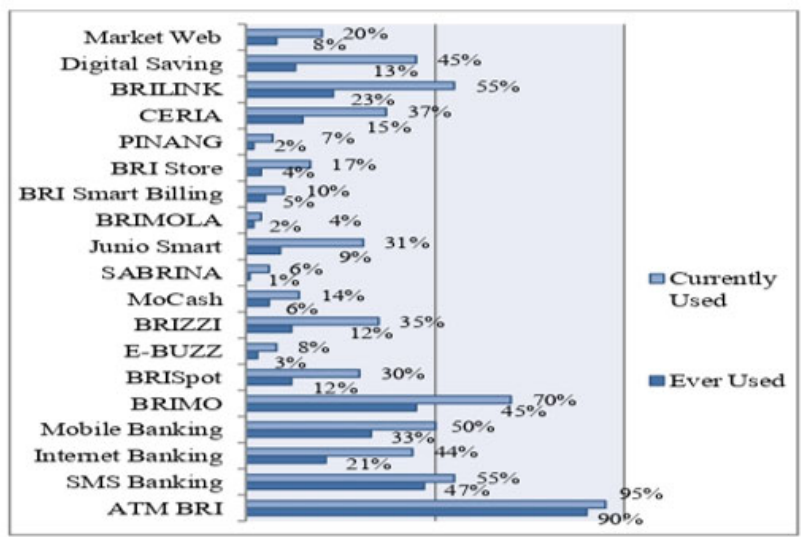

Fig 4. Service BRI E-Banking

In Figure 3, it can be seen the characteristics of respondents based on occupation are the most respondents with professions as students with a percentage of $47 \%$. The characteristics of respondents based on the intensity of transactions e-banking BRI during the month were 1-3 times with a percentage of $57 \%$. Characteristics of respondents based on the last time the most transactions were this week with a percentage of $41 \%$.

Characteristics of respondents based on knowledge of BRI bank services, the most widely known is e-banking services with a percentage of 52\%. The following are the results of the characteristics of respondents based on services e-banking BRI that have been and are currently being used and the reasons for using e-banking BRI can be seen in the following diagram:

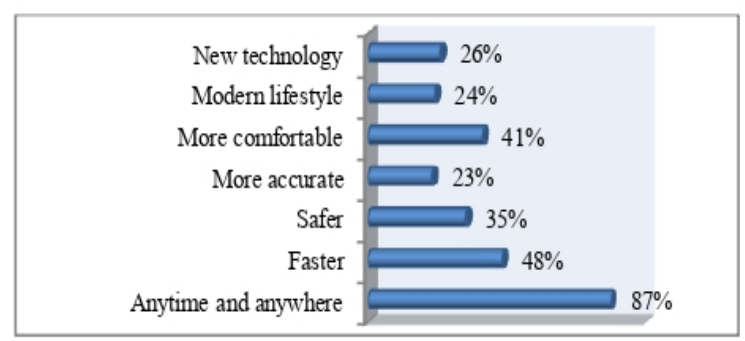

Fig 5. Reason for using E-Banking

The results of the answers of 100 respondents based on the services that have been used and are being used the most are BRI ATM with the percentage of services ever used by $90 \%$ and services currently in use increasing by $95 \%$. The main reason for using e-banking the BRI most is anytime and anywhere with a percentage of $87 \%$.

\subsection{Research Instrument Test}

The purpose of research instrument testing is to see if the statement items or indicators can be used for research. Validity and reliability testing were used in the test instrument in this research. Specifically, a questionnaire instrument. The validity test is used to test the level of accuracy of the statement items or indicators used, provided that $r_{\text {count }}>r_{\text {table. A questionnaire is }}$ 
said to be valid if the questions on the questionnaire can reveal something that the questionnaire wants to measure (Ghozali, 2016: 52). The number of respondents in this study were 100 respondents so that the $r_{\text {table }}$ was 0.196 with a significance level of $0.05(5 \%)$. From the results of the validity of $\mathrm{X}$ and $\mathrm{Y}$ using SPSS ver. 25 it can be concluded that all variable statements have a value of $r_{\text {count }}>r_{\text {table }}(0.196)$ which means the statement is valid.

Variable $\mathrm{X}$ and variable $\mathrm{Y}$ indicate that each item of the statement is able to measure the relationship between the quality of e-banking services to customer satisfaction. The reliability test aims to determine the consistency of the respondent's answers in this study. The requirements for reliability are if a variable is reliable if the value is Cronbach alpha $>0.60$ (Ghozali, 2016:47). Reliability test results of 100 respondents as follows: From the results of the reliability test show that for the variable quality of e-banking services, Cronbach's alpha is $0.957(0.957>0.60)$ so that the variable of service quality e-banking is reliable. While the Cronbach alpha variable for customer satisfaction is $0.922(0.922>0.60)$ which means reliable. Questionnaire items from the two variables, namely the quality of services e-banking $(\mathrm{X})$ and customer satisfaction (Y), it is known that all the answers to the statement item questionnaire are reliable, because Cronbach's Alpha value is greater than $>0.60$.

\subsection{Classical Assumption Test}

Classical assumption test is conducted to determine whether the data used is feasible to be analyzed because not all data can be analyzed by regression so that it must first meet the classical assumptions. In this study, the classical assumption test consisted of a normality test and a heteroscedasticity test. The normality test aims to determine whether the data from the variables in the study are normally distributed or not. Normality test in this study using the Normal P Plot graph.

The results of the normality test using SPSS ver. 25 by looking at the Normal P-Plot graph, which show the spread of the points spreads around the line and the points follow the direction of the diagonal line, so it can be said that the data in the regression model has been normally distributed. The heteroscedasticity test was carried out to test whether in a regression model there was an inequality of variance and residuals in the regression model used from observations to other observations. Heteroscedasticity test to detect the presence of heteroscedasticity symptoms was carried out using the graph technique Scatterplott. As for the results of the heteroscedasticity test using SPSS ver. 25 in this study, it can be seen that there is no certain pattern because the points spread irregularly over the $\mathrm{X}$ and $\mathrm{Y}$ axes, which means that there is no heteroscedasticity.

This analysis was employed in this study to get a better understanding of the data distribution of the research variables, namely the quality of e-banking services (X) and customer satisfaction (Y), which were well-executed.

Table 2. Results of Descriptive Statistical Analysis

\begin{tabular}{|l|l|l|l|l|l|}
\hline \multicolumn{7}{|c|}{ Descriptive Statistics } \\
\hline & $\mathrm{N}$ & Min & Max & Mean & $\begin{array}{l}\text { Std. } \\
\text { Deviation }\end{array}$ \\
\hline $\mathrm{X}$ & 100 & 16 & 64 & 51,25 & 9,308 \\
\hline $\mathrm{Y}$ & 100 & 5 & 20 & 15,50 & 3,341 \\
\hline $\begin{array}{l}\text { Valid N } \\
\text { (listwise) }\end{array}$ & 100 & & & & \\
\hline
\end{tabular}


Table 2 shows that the two variables in this study have $\mathrm{N} \mathrm{100,} \mathrm{which} \mathrm{indicates} \mathrm{there} \mathrm{are} 100$ responses to the questionnaire, with the variable $\mathrm{X}$ quality of service receiving a minimum score of 16, a maximum score of 64, and a mean (mean) of 51.25 and a standard deviation of 9.308. Then there's variable Y customer satisfaction, which has a minimum score of 5 and a maximum score of 20, with a mean of 15.50 and a standard deviation of 3.341 .

The value mean of the service quality variable e-banking $(\mathrm{X})$ is 51.25 which is greater than the standard deviation of 9.308 and the mean of customer satisfaction (Y) is 15.50, which is greater than the standard deviation of 3.341. As a result, because the average value of each variable is greater than the standard deviation value, it may be stated that the data distribution was well done.

Simple linear regression analysis was conducted to examine the effect of the independent variable, namely the quality of e-banking services $(\mathrm{X})$ on the dependent variable, namely customer satisfaction (Y).

Table 3. Results of Simple Linear Regression Analysis

\begin{tabular}{|c|c|c|c|c|c|}
\hline \multicolumn{6}{|c|}{ Coefficients $^{\mathrm{a}}$} \\
\hline \multirow[t]{2}{*}{ Model } & \multicolumn{2}{|c|}{$\begin{array}{c}\text { Unstandardized } \\
\text { Coefficients }\end{array}$} & \multirow{2}{*}{$\begin{array}{c}\text { Standardized } \\
\text { Coefficients }\end{array}$} & \multirow[b]{2}{*}{$\mathrm{t}$} & \multirow[b]{2}{*}{ Sig. } \\
\hline & $\mathrm{B}$ & Std. Error & & & \\
\hline (Constant) & ,397 & 1,078 & & ,368 &, 713 \\
\hline $\begin{array}{l}\text { Quality of } \\
\text { E-Banking Service }\end{array}$ & ,295 & ,021 &, 821 & 14,236 & ,000 \\
\hline
\end{tabular}

From the table above it is known that the simple linear regression equation is:

$$
\mathrm{Y}=0.397+0.295 \mathrm{X}
$$

The regression equation can then be translated as follows:

a. The constant is 0.397 , which means that if the e-banking service quality coefficient $(\mathrm{X})$ is zero or non-existent, the customer satisfaction value is 0.397 .

b. The regression coefficient of the service quality variable e-banking is 0.295 , which means that for every $1 \%$ rise in the $\mathrm{X}$ variable, the $\mathrm{Y}$ variable increases by 0.295 , and the regression coefficient is positive, implying that the variable's effect is positive.

Coefficient of determination test in this study useful to measure the ability of the independent variable is the quality of services e-banking to explain the dependent variable is customer satisfaction. The following are the results of the coefficient of determination test obtained by the researcher, namely:

Table 4. Results of Determination Coefficient Test

\begin{tabular}{|l|c|c|c|c|}
\hline \multicolumn{4}{|c|}{ Model Summary $^{\mathbf{b}}$} \\
\hline Model & R & R Square & Adjusted R Square & Std. Error of the Estimate \\
\hline
\end{tabular}




\begin{tabular}{|l|l|r|r|r|}
\hline 1 & $821^{\text {a }}$ &, 674 & 674,671 & 1,917 \\
\hline \multicolumn{2}{|l|}{ a. Predictors: (Constant), Quality of E-Banking Service } \\
\hline
\end{tabular}

The results of the coefficient of determination test get a result of 0.674 meaning that the quality of services e banking has a contribution of $67.4 \%$ to customer satisfaction, while the remaining $32.6 \%$ is influenced by other factors or variables not explored in this study. These results indicate that there is an influence between the quality of e-banking services on customer satisfaction with the influence being fairly strong.

\subsection{Hypothesis Test (t-test)}

Hypothesis test ( $\mathrm{t}$-test) is used to determine whether there is an influence between the independent variable, namely the quality of e-banking services, on the dependent variable, namely customer satisfaction. The criteria for accepting the hypothesis if $t_{\text {count }}>t_{\text {table }}$ then the independent variable affects the dependent variable, and vice versa. With a significance value of $5 \%$, it means that if sig $<0.05$ then there is an influence between variables.

From the results of the hypothesis test (t-test) using SPSS ver. 25, the quality of ebanking services has an effect on customer satisfaction. It is known that the $t_{\text {count }}$ for the quality of services is e-banking 14,236. The value of $t_{\text {table }}$ for a sample of 100 respondents can be found by looking for the value $\mathrm{df}=\mathrm{nk}=100-2=98$. So that the value of $\mathrm{t}_{\text {table }}$ is 1.984 . This can be seen in the following conclusions:

a. If the value of $t_{\text {count }}>\mathrm{t}$ table then Ho is rejected. And if the value of $\operatorname{sig}<0.05$, then the variable has a positive effect.

b. Seen from the table above, the significance value $<0.05(0.000<0.005)$ means that the quality of $e$-banking services has a significant effect on customer satisfaction.

So, it can be concluded that the variables of service quality e-banking (X), namely speed, security, accuracy, and trust have a positive and significant effect on customer satisfaction (Y) during the covid-19 pandemic.

\section{Discussion}

The objectives to be achieved in this study are to determine the quality of e-banking services at the BRI Panakkukang Branch during the Covid-19 pandemic affected customer satisfaction and to determine differences in the quality of services e-banking BRI during the Covid-19 pandemic. In this study, descriptive analysis, basic linear regression analysis, and document review were employed as data analysis techniques. Based on the results of the analytical procedures used, the following is a summary of the findings:

\subsection{Quality of E-Banking Services at BRI Panakkukang Branch During the Covid 19 Pandemic}

Speed. The quality of e-banking services at BRI Panakkukang Branch during the Covid-19 pandemic on the indicator of speed is included in the category very good speed quality, according to the results of study processed by researchers. The indicator speed in this study contains four statement items. Statements on transactions made using service facilities e- 
banking BRI's can be made at any time and from any location, with no time limit, or within 24 hours during the Covid-19 pandemic, resulting in the highest score among all statements.

This demonstrates that the BRI Panakkukang Branch's e-banking service is currently the customer's preferred method of transaction, as a result of the government's recommendation during the Covid -19 pandemic to avoid crowds and maintain a safe distance, so that transactions can be completed faster and easier by using e-banking services. It is more convenient because it eliminates the need for customers to visit the bank. This is in line with the theory of Lovelock and Gummesson (2004) according to which the element of service quality speed can make it easier for clients to complete transactions more quickly, hence enhancing customer satisfaction with transaction speed and ease.

While the statement that received the lowest score from respondents on the indicator speed was the second statement regarding the speed of responding to customer complaints from services e-banking BRI during the Covid -19 pandemic. This indicates that the system for handling customer complaints related to e-banking services from BRI Panakkukang Branch is not optimal.

Security. The quality of e-banking BRI services at the Panakkukang Branch during the Covid -19 pandemic on indicators is security included in the category of very good security quality, according to the results of study processed by researchers. Customers may be influenced to utilize e-banking by two important factors: security and privacy (Wu, Chen and Chang, 2016). There are four statement items in this study's indicator security. The following is a declaration about e-banking service trust.

When compared to other statements, BRI's is the safest for completing transactions and moving funds during the Covid -19 pandemic. This demonstrates that customers have a high level of trust in the security of using e-banking BRI Branch Panakkukang to conduct transactions and transfer monies. This is supported by the theory of Park and Kim in Sukma (2012) which says that security is important in building trust by reducing consumer concerns about misuse of personal data and data transactions that are easily damaged. Meanwhile, the statement on the guarantee that there will be no theft of customer funds utilizing BRI e-banking services during the Covid -19 pandemic obtained the lowest score from respondents on the indicator security.

This is in line with the researchers first observations of the issues that customers frequently complain about when utilizing BRI Panakkukang Branch e-banking, one of which is frequent account balance loss.

Accuracy. The quality of e-banking BRI services at the Panakkukang Branch during the covid-19 pandemic on the indicator is accuracy included in the category of very good accuracy quality, according to the results of study processed by researchers. According to Trisnawati and Fahmi (2017:176), refers to a bank's capacity to give exact and accurate information to consumers in the event of a problem, as well as a service provider's ability to make assurances. There are four statement items in this study's indication accuracy. The highest score was given to the statement on the suitability of the information gathered from the same BRI e-banking service at the bank during the Covid-19 pandemic.

This demonstrates that clients believe the information collected by using the e-banking service at BRI Panakkukang Branch is the same as that obtained by the bank. While the statement that obtained the lowest score from the respondent on the indicator accuracy was the same as the statement that received the lowest score from the respondent, there were two statements that earned the same and lowest score from the respondent, namely, the accuracy of 
transaction records from services e-banking BRI received during the Covid-19 pandemic, and statements regarding the clarity and accuracy of information from services e-banking BRI received during the Covid-19 pandemic, so that in the event it needs to be improved, for example, by always giving notification, information, or calling the service online banking is accurate, precise, and clear.

Trust. The quality of e-banking services at BRI Panakkukang Branch during the Covid-19 pandemic on the indicator trust is at a very good level of trust quality, Once the services provided by the bank can satisfy customers, it will build customer trust. This is supported by other research in (Rajab, 2018) that increasing trust is heavier than maintaining the trust that has been given.

The indicator trust in this study contains four statement items. Statements regarding trust in services e-banking BRI can help in transactions during the Covid-19 pandemic, obtaining the highest score compared to statements other. This shows that customers believe that by transacting through the service e-banking at BRI Panakkukang Branch can assist customers in making transactions during the Covid-19 pandemic. The results of this statement are also supported by other research in (Mathory, 2013) which explains that customers who have more positive beliefs about the perceived behavior relative advantage during the use of mobile banking, thus forming a better attitude in building trust in the use of e-banking, especially mobile banking.

Meanwhile, the statement that received the lowest score from respondents on the indicator trust was a statement regarding the level of customer trust in BRI Panakkukang Branch in providing a sense of security by using e-banking services during the Covid -19 pandemic. This shows that BRI Branch Panakkukang has not been maximal in providing a sense of security to use e-banking services. This can cause customers to feel distrustful of using e-banking services BRI.

Overall, the quality of e-banking BRI services which consist of indicators of speed, security, accuracy, and trust during the Covid-19 pandemic, obtained an average value of 320.2 , which the researchers rounded to 320 or $80 \%$ of the expected $100 . \%$, meaning that it is in the category of excellent service quality.

Customer Satisfaction. From the results of research processed by researchers, it shows that customer satisfaction with the quality of e-banking services at BRI Panakkukang Branch is in the very good category. Tjiptono (2014) states that consumer satisfaction is a situation shown by consumers when their needs and desires match what is expected and are well fulfilled. The customer satisfaction variable in this study contains five statement items. Statements regarding overall customer satisfaction with services e-banking BRI during the Covid-19 pandemic received the highest score compared to other statements.

This shows that the overall level of customer satisfaction with service e-banking at BRI Panakkukang Branch is very good. Meanwhile, the statement that received the lowest score from the respondents was a statement regarding the level of customer complaints against services e-banking BRI during the covid-19 pandemic. This is in line with the initial observations of researchers who received several complaints from customers in using services e-banking BRI at the Panakukkang Branch during the Covid-19 pandemic.

The respondent's remark is in line with Umar's theory in Hendri (2009), which states that satisfaction is divided into two types: functional and psychological satisfaction. The satisfaction derived from a product's advantages is known as functional satisfaction. The satisfaction derived from a product's advantages is known as functional satisfaction. Psychological fulfillment, on the other hand, is derived from the product's intangible characteristics. According to the above 
description, functional satisfaction for customers is measured in terms of benefits received from e-banking BRI Panakkukang Branch.

The more benefits received from e-banking BRI's, the more satisfied consumers will be. Psychological satisfaction is a sense of pride in using e-banking BRI's services. Overall customer satisfaction e-banking BRI's during the Covid-19 pandemic obtained an average value of 310 or $77.5 \%$ of the expected $100 \%$, meaning that it is included in the category of very good customer satisfaction.

\subsection{The Effect of Quality of Services E-Banking at BRI Panakkukang Branch during the Covid-19 Pandemic on Customer Satisfaction}

The effect of the quality of e-banking services during the covid-19 pandemic on customer satisfaction in this study contributed $67.4 \%$. While the remaining $32.6 \%$ is influenced by other factors not examined in this study. This is supported by previous research proposed by Lovelock and Gummesson (2004) which suggests that the quality of e-banking services consisting of speed, security, accuracy, and trust is something important. to be analyzed and can affect customer satisfaction.

Based on the results of the data analysis that has been described, it shows that the quality of e-banking services has a positive and significant influence on customer satisfaction. According to Umar in Hendri (2009) there are two main aspects that influence consumer attitudes, namely socio-cultural factors consisting of culture, special culture, social class, social groups, references, and family.

Second, psychological factors consisting of motivation, perception, learning process, beliefs and attitudes. So it can be interpreted that the better the quality of e-banking services provided, the higher the satisfaction. Vice versa, the worse the service provided, the lower the level of satisfaction.

\subsection{Differences in Quality of Services E-Banking at BRI Panakkukang Branch During} the Covid-19 Pandemic

The technique used by researchers to analyze differences in the quality of services ebanking at BRI Panakkukang Branch during the Covid-19 pandemic, namely by using document review.

Document Analysis. During the Covid-19 pandemic, various additional features from several service facilities at e-banking BRI the Panakkukang Branch, including the following:

Table 2. Document Analysis

\begin{tabular}{|c|l|l|l|l|}
\hline No & \multirow{2}{*}{ Document } & \multicolumn{2}{|c|}{ Aspects Reviewed } & \multicolumn{1}{|c|}{ Description } \\
\cline { 3 - 4 } & $\begin{array}{c}\text { Services } \\
\text { Of } \\
\text { E-Banking } \\
\text { BRI }\end{array}$ & $\begin{array}{c}\text { Latest Features } \\
\text { During the Covid-19 } \\
\text { Pandemic }\end{array}$ & \multicolumn{1}{|c|}{$\begin{array}{l}\text { BRIBrainhas the four } \\
\text { functions are BRILink } \\
\text { Score, Credit Scoring to be } \\
\text { more accurate map profile } \\
\text { customers properly and make } \\
\text { BRI faster find }\end{array}$} \\
\hline 1 & $\begin{array}{l}\text { Innovation } \\
\text { Service }\end{array}$ & BRIBrain & $\begin{array}{l}\text { BRIBrain an platform } \\
\text { artificial intelligence dan } \\
\text { machine learning }\end{array}$ \\
\hline
\end{tabular}




\begin{tabular}{|c|c|c|c|c|}
\hline \multirow[t]{2}{*}{ No } & \multirow[t]{2}{*}{ Document } & \multicolumn{2}{|c|}{ Aspects Reviewed } & \multirow[b]{2}{*}{ Description } \\
\hline & & $\begin{array}{l}\text { Services } \\
\text { Of } \\
\text { E-Banking } \\
\text { BRI }\end{array}$ & $\begin{array}{l}\text { Latest Features } \\
\text { During the Covid-19 } \\
\text { Pandemic }\end{array}$ & \\
\hline & & & & $\begin{array}{l}\text { potential crime on transaction } \\
\text { quickly. }\end{array}$ \\
\hline \multirow[t]{6}{*}{2} & \multirow{6}{*}{$\begin{array}{l}\text { Enhancer's } \\
\text { features } \\
\text { in the } \\
\text { services } \\
\text { e-banking }\end{array}$} & ATM BRI & $\begin{array}{l}\text { Amenities } \\
\text { Cash Advance through } \\
\text { the ATM LINK }\end{array}$ & $\begin{array}{l}\text { This facility is used for cash } \\
\text { withdrawal for card } \\
\text { holders Credit BRI. }\end{array}$ \\
\hline & & $\begin{array}{l}\text { Internet } \\
\text { Banking }\end{array}$ & $\begin{array}{l}\text { Change User ID } \\
\text { BRIMO anytime } \\
\text { through internet } \\
\text { banking }\end{array}$ & $\begin{array}{l}\text { This feature is useful for } \\
\text { customers who want to change } \\
\text { the User ID BRIMO anytime } \\
\text { so that transactions } \\
\text { BRIMO more secure. }\end{array}$ \\
\hline & & $\begin{array}{l}\text { Mobile } \\
\text { Banking }\end{array}$ & Fingerprint & $\begin{array}{l}\text { This facility is used to } \\
\text { for improve security for users } \\
\text { of mobile banking BRI. }\end{array}$ \\
\hline & & BRIMO & $\begin{array}{l}\text { Transactions with } \mathrm{QR} \\
\text { codes }\end{array}$ & $\begin{array}{l}\text { This facility serves to } \\
\text { the facilitate customers in terms } \\
\text { of transaction simply by using } \\
\text { the QR code on BRIMO. }\end{array}$ \\
\hline & & BRIZZI & Port Transaction & $\begin{array}{l}\text { Facility This facility is used to } \\
\text { for make it easier } \\
\text { make customers transactions } \\
\text { at the port. }\end{array}$ \\
\hline & & BRILINK & $\begin{array}{l}\text { Link to the location } \\
\text { nearest Agent.BRILINK }\end{array}$ & $\begin{array}{l}\text { This facility is used to for make } \\
\text { it easier customers to find } \\
\text { agents BRILINK according to } \\
\text { the location closest. }\end{array}$ \\
\hline 3 & $\begin{array}{l}\text { Online } \\
\text { KPR Policy }\end{array}$ & BRISPOT & $\begin{array}{ll}\text { Simulation } & \text { of } \quad \text { KPR } \\
\text { (House } & \text { Ownership } \\
\text { Credit) } & \end{array}$ & $\begin{array}{l}\text { This facility is used } \\
\text { to facilitate customers to find out } \\
\text { the } \\
\text { rate installment, payment first, } \\
\text { amount interest and period time } \\
\text { if they want to use KPR. }\end{array}$ \\
\hline
\end{tabular}




\begin{tabular}{|c|c|c|c|c|}
\hline \multirow[t]{2}{*}{ No } & \multirow[t]{2}{*}{ Document } & \multicolumn{2}{|c|}{ Aspects Reviewed } & \multirow[b]{2}{*}{ Description } \\
\hline & & $\begin{array}{c}\text { Services } \\
\text { Of } \\
\text { E-Banking } \\
\text { BRI }\end{array}$ & $\begin{array}{l}\text { Latest Features } \\
\text { During the Covid-19 } \\
\text { Pandemic }\end{array}$ & \\
\hline \multirow[t]{2}{*}{4} & $\begin{array}{l}\text { Document } \\
\text { Cooperation }\end{array}$ & $\begin{array}{l}\text { Junio } \\
\text { Smart }\end{array}$ & $\begin{array}{l}\text { Webinar and giving } \\
\text { two laptop unit } \\
\text { directly free } \\
\text { for schools which } \\
\text { include in the district } \\
\text { Panakkukang } \\
\text { and has use Junio } \\
\text { Smart. }\end{array}$ & $\begin{array}{l}\text { BRI Branch Panakkukang helps } \\
\text { schools including } \\
\text { students, parents and teachers } \\
\text { to improve the } \\
\text { quality of distance learning in the } \\
\text { midst of a pandemic with the } \\
\text { Junio Smart application. }\end{array}$ \\
\hline & & BRISPOT & $\begin{array}{l}\text { KUR Loan digital } \\
\text { works same with } \\
\text { e- commerce } \\
\text { like shopee, } \\
\text { shopee, Gojek, Grab }\end{array}$ & $\begin{array}{l}\text { BRI Branch } \\
\text { Panakkukang accelerate KUR } \\
\text { distribution digitally } \\
\text { via cooperation with e- } \\
\text { commerce as form of } \\
\text { support SMEs so that survive } \\
\text { and rise from the covid } 19 \\
\text { pandemic }\end{array}$ \\
\hline
\end{tabular}

Description of Document Review Results. Based on the analysis of the above documents, the differences in the quality of services can be interpreted e-banking at BRI Panakkukang Branch during the Covid -19 pandemic as follows:

Speed. The difference in the quality of e-banking services at BRI the Panakkukang Branch during the covid-19 pandemic on the indicator speed can be seen in the first service innovation document issued, namely BRIBrain. BRIBrain can help BRI Panakkukang Branch to share customer profiles appropriately which makes communication methods with customers faster and more accurate (customer profiling score). Then in the second document, the latest features from BRIMO are transactions with QR codes and the latest feature from BRIZZI, namely being able to transact at ports, making it easier and faster for customers to transact during the Covid19 pandemic anywhere and anytime.

This is in line with the results of research processed by researchers on BRIMO services which have increased from services that have been used by $45 \%$ up to services that are currently being used by $70 \%$. and BRIZZI from $12 \%$ used services to $35 \%$ currently used services. So it can be said that the quality of services e-banking at BRI Panakkukang Branch, the indicator speed during the pandemic Covid-19, is different from the latest facilities issued to improve the speed quality services at of e-banking BRI Panakkukang Branch. Security. The difference in the quality of e-banking services at BRI Panakkukang Branch during the Covid-19 pandemic on the indicator security can be seen in the first document of the BRIBrain service innovation which allows BRI Branches to find potential crimes, such as fraud or fraud that can occur. to customers or companies (fraud score). BRIBrain can quickly detect crimes in transactions.

Furthermore, the second document is the latest feature of internet banking, namely being able to change the BRIMO User Id at any time and the addition of a fingerpint (fingerprint) on mobile banking can also improve the quality of security for users e-banking of BRI 
Panakkukang Branch during the Covid-19 pandemic. This is in line with the findings of study conducted by academics on internet banking services, which have climbed from 21 percent usage to 44 percent usage. From services that have been used by $33 \%$ to $50 \%$ of services now in use, mobile banking is becoming more popular. As a result, the quality of e-banking services at BRI Panakkukang Branch, which served as a security indicator during the Covid-19 pandemic, differs from the most recent facilities offered to strengthen the safety quality of ebanking services at BRI Panakkukang Branch.

Accuracy. The difference in the quality of e-banking services at BRI Panakkukang Branch during the Covid-19 pandemic on the indicator accuracy can be seen in the first document of BRIBrain service innovation. With BRIBrain, the BRILink Agent eligibility assessment is more practical in real time. BRIBrain makes the BRILink agent assessment procedure more accurate. Then in the second document, the link facility provided by BRI Panakkukang Branch for customers to find the location of BRILink agents according to the customer's closest location can also increase the level of accuracy and make it easier for customers to find BRILink agents. And the third document, the mortgage simulation feature online from BRISpot, can increase the level of accuracy in calculating installments, initial payments, and interest rates.

This is in line with the results of research processed by researchers on the BRILink service which has increased from services that have been used by $23 \%$ up to services that are currently being used by $55 \%$. And BRISpot from services that have been used by $12 \%$ to $30 \%$ of services that are currently being used. So it can be concluded that the quality of services e-banking BRI at Panakkukang Branch on the indicator accuracy during the Covid-19 pandemic is different from the latest facilities issued to improve the quality of the accuracy of e-banking services at BRI Panakkukang Branch.

Trust. The difference in the quality of e-banking services at BRI Panakkukang Branch during the Covid-19 pandemic on the indicator trust can be seen in the first document of BRIBrain service innovation. BRIBrain can help assess the credit worthiness of prospective debtors faster, which makes loan approvals and payments can be made immediately, so that the risk of bad loans can be reduced to the lowest possible level. Furthermore, the fourth document of the service Junio Smart as one of the service facilities at e-banking BRI Panakkukang Branch, held a free webinar and distribution for schools included in the Panakkukang area and recommended Junio Smart to support the teaching and learning process during the Covid-19 pandemic. And cooperation in distributing KUR digitally with several e-commerce carried out by PT. Bank Rakyat Indonesia (Persero) Tbk, Panakkukang Branch so that it can help customers to continue to receive People's Business Credit (KUR) online during the covid-19 pandemic which in turn is able to generate trust from customers and stakeholders to PT. Bank Rakyat Indonesia (Persero) Tbk, Panakkukang Branch.

This is in line with the results of research processed by researchers on services Junio Smart which experienced an increase from services that had been used by $9 \%$ up to services that were being used by $31 \%$. Then BRISpot from services that have been used by $12 \%$ to $30 \%$ of services that are currently being used. So it can be concluded that the quality of services e-banking BRI at Panakkukang Branch on the indicator trust during the Covid-19 pandemic has experienced differences with the latest facilities issued to improve the quality of trust services in e-banking at BRI Panakkukang Branch.

From the additional features of service e-banking at BRI Panakkukang Branch during the covid-19 pandemic, it can be said that in retaining customers or customers, PT Bank Rakyat Indonesia (Persero) Tbk, Panakkukang Branch maintains relationships with customers in a proactive category, namely continuing to innovate. and the addition of features from time to time to the service e-banking BRI Panakkukang Branch which aims to increase product usage. 
With this feature, customers will get more benefits from using service e-banking at BRI Panakkukang Branch.

\section{Conclusions}

The quality of e-banking services at BRI Panakkukang Branch received a percentage of the indicators for speed $80.75 \%$, security $78.67 \%$, accuracy $79.8 \%$ and trust $81.05 \%$ from the expected $100 \%$ so that overall, the average score was obtained. The average is 320.2 which the researchers rounded to 320 or $80 \%$ of the expected $100 \%$, meaning that it is included in the very good category, and the customer satisfaction variable gets an average value of 310 or $77.5 \%$ of the expected $100 \%$. So, in this case the researcher can conclude from the four indicators above, it shows that the quality of e-banking services at BRI Panakkukang Branch has good service quality.

The quality of e-banking services consisting of speed, security, accuracy and trust has a positive and significant impact on customer satisfaction during the covid-19 pandemic. This is obviously proven by the test results that the e-banking service quality variable $(\mathrm{X})$ has a positive coefficient with $t_{\text {count }}=14,236>t_{\text {table }}=1.984$ or sig $=0.00<0.05$, then $\mathrm{H}_{\mathrm{a}}$ is accepted. The result of the coefficient of determination $\left(\mathrm{R}^{2}\right)$ obtained the results of 0.674 . This shows that the effect of service quality e-banking on customer satisfaction during the covid-19 pandemic is $67.4 \%$, while the rest is influenced by other factors not examined in this study.

According to the findings of a document review conducted by researchers, there were differences in the quality of e-banking services at BRI Panakkukang Branch during the Covid19 pandemic with the latest features and innovations issued to improve the quality of services ebanking at BRI the Panakkukang Branch which consists of BRIBrain innovations, facilities Cash Advance via ATM LINK, changing BRIMO User ID via Internet Banking, adding fingerprints to Mobile Banking, adding transaction features using QR codes on BRIMO, adding transaction features at ports on BRIZZI, link facility to the nearest BRILINK Agent location, mortgage simulation facility on BRISpot, free webinar and two laptop units on service Junio Smart, digital KUR loans in collaboration with several ecommerce sites on BRISpot.

The researchers make several recommendations to the company based on the abovementioned findings and exposure. The indicator security, for example, is one of the indicators with the smallest value. As a result, the researcher recommends that the security mechanism for BRI Panakkukang Branch's service e-banking be strengthened further so that customer accounts do not lose balance. Second, in order to preserve customer happiness, the company can build close relationships with consumers by providing information on the availability of service facilities at the Panakkukang Branch of the BRI e-banking system and providing contact information for customer complaints.

\section{References}

[1] Anggraeni, NMS, and Yasa, NNK.: E-Service Quality on Customer Satisfaction and Loyalty in Using Internet Banking. Vol.16, no.2, pp. 329-343. Journal of Finance and Banking (2012)

[2] Ghozali, Imam.: Multivariate Analysis Application with IBM SPSS Program. Diponegoro University Publishing Agency, Semarang (2016)

[3] Henry, John.: Marketing Research. Gunadarma University, Jakarta (2009) 
[4] Imandiar, Yudhisthira.: COVID-19 pandemic, BRI Recorded 2.73 Billion E Banking Transactions, https://finance.detik.com/moneter/d-5011970/pandemic-covid-19-bri-catat 273-miliar-transaksi-ebanking. Accessed on November 11, 2020 at 12.30 WITA (2020)

[5] Indrawati.: Research Methods Management and Business Convergence of Communication and Information Technology, Refika Aditama, Bandung (2015)

[6] Krishna, G. Shiva.: A Study on E-Banking to Improve Customer Base with Reference to HDFC Bank 1td, Eluru (apindia). Vol.4, issue 3, International Journal of Research and Computational Technology (2012)

[6] Lovelock, Christopher., and Gummesson, Evert.: Whither Services Marketing: In Search of a New Paradigm and Fresh Perspectives. Vol 7, no.20, Journal of Service Research (2004)

[7] Mathory, EAS.: Analysis of the factors that cause customers to use mobile services banking: technology acceptance model approach: a case study of PT Bank XYZ. University of Indonesia, Jakarta (2013)

[8] Rajab, Hairunas.: The Relationship Between Trust and Buying Interest in Online Stores. Vol 2, no 3, pp. 169. International Journal of Social Science and Business (2018)

[9] Sharma, Himani.: Bankers' Perspectives on E-Banking. Vol.1, issue 1. Global Journal of Research in Management (2011)

[10] Sugiyono.: Qualitative Research Methods: For research that is: explorative, enterpretive, interactive, and constructive. Alfabetha, Bandung (2017)

[11] Sukma, Abdurrahman Adi.: Analysis of Factors Influencing Purchase Decisions through Social Networking Websites. Gunadarma University, Jakarta (2012)

[12] Tjiptono, Fandy.: Service Marketing: Principles, Applications, and Research. Andi Offset, Yogyakarta (2014)

[13] Trisnawati, OM, and Fahmi, S.: The Effect of Electronic Service Quality (ESVQUAL) on Customer Satisfaction of Mobile Banking Users. Vol.4, no.2, Indonesian Journal of Business Management (2017)

[14] Wu, Wen-Tsung., Chen, Chie-Bein., and Chang, Chiao-Chen.: Examining Paid Mobile Application Customer Loyalty: The Moderating Effect of Switching Costs. Vol. 6, issue 2, pp. 100-117. Journal of Business and Economic Research (2016) 